minous. Up to the time of deatl conscionsness was retained, and the cardite sounds mantilined their purity. At the necropsy, ulecrative cndocarditis of the left sille was found, along with a large elot attached to the wall of the auricle, and prolonged into the ventricle, where it was adherent to the chordse tendinese. The aurieulo-rentrieular valve was perforated; the artic competent, but inflamed. At the bifurestion of the alorta there was a large fibrinous clot, not adherent to the vessel. The spinal meninges and the cord itself were much congested in the lumbill region, the kidneys were studded with infircts, the spleen congested, and its main artery obliterated; there were no signs of embolism in the brain, the lungs, or the liver. The authors eite several eases of aortic embolism and thrombosis, and point out that the former is more frequently met with than the littere. To explain why there was no ummmur in their case, when the clot would be expected to prothce one, MMI. Barie and Du Castel, under the supervivion of M. Potain, arimged a series of tubes of the same calibre, through which currents of wilter (at the same pressure) flowerl. In these tubes wore placed diaphrayms of the sime metal, pertorated by apertures of different sllipe and position. They found that the intensity of the murmur was the same in all, whatever the form and situation of the orifice might be. Then to make out whether the material of which the olstales were composed hat any influcher, thry remored the diaphragms, and substituted foreign bodies of difterent uature aud resistance. The murmur was loud and distinct when the obstale was land and resistant; lout when it was soft and velvety the nummr almost disalperined. 'They therefore eonclude: 1. That the form of the orifice has no influrbere over the production of the mummur ; 2. That the consistene of the walls of the orifice exerts it wotable iuflucuee upon the intensity of the mumur,-London Nled. Fiecorel, Jee. 1881 .

\title{
Esophregeal Lleer from Digestion.
}

Professor Quxcke, of Kiel, pullished some time sinec oberrations to show that ulecrs mily occur in the asophlagus from the action of the gistrie juire. Three cuses are now (Deut. Archiv fü Klin. Med.) published in support of this. 1. The first case was that of a patient suffering tiom eancer of both ovaries. The ulecr was in the lower pert of the osophlugus; and in this, as in the other cases, the absence of cancer at the spot wis provet by microscopic eximination, as was also the possibility of corrosion ante mortem or digestion post mortem. 2. The sccond wals that of a patient affecterl with ovarian eyst, in whom an maplangeal ulcer in the lower half had perforated into the right plemal cavity. 3. 'The thirl case was that of a man, 50 years of age, calchectic, anch to all appestunce sutfering from cancer. The post-mortem examination, however, showed the canse to be marked narrowing of the cesoplisteal opening of the stomach by a cientricial stricture, evidently the remains of a previous ulcer involving the neighbouring musous membrane, and giving rise to muscular ly!jertrophy of the ratophagus and elnonie swelling of its mucons membrine.-London Med. Record, Decmber 15, 1881.

\section{Encysted Dropsy of the Peritoneum.}

At the meeting of the Harveian Society of London, on Jall. 5, Mr. Kxows L.EY Thonston read a paper on this sulject. The discase is very lane, but he him met witl two cases in his hospital practice in the last three months, and this showed that we must be prepared to diagnose it from other abdominal cniargements. Correct diagnosis being all important in these cases for suecessful treat- 
ment, he alluded to the small amount of information on the sulject to be found in either the gener:ll or special text-books. IIe quoted at some length a casce in Mr. Spencer Wells's work on Diseases of the Oraries, which very roscly resembled one of his own, and alluded to the opinions of 1) ws. West and Peaslea. The statemunts of the latter be regarded as misleading, the errors arising, in his opinion, from an attempt to grencralize from imperfect data. lle pointerl out that it is important to distingnish this disease from the nuch commoner condition in whish partisl collections of flnid oecur in the peritoneum around milignemt growths. His own cases were then filly recorded.

Case 1 was that of a woman of forty-five, supposed to lave an ovarian tumour, which was also supposed to have rmptured into the peritoneum while she was uncler the author's observation. Suppression of urine led to tapping of the peritoneum, which gave temporary relief, but she died with uremic symptoms without further operation. 'The post-mortem revealed very andranced granular discase of the kicheys, a latge spleen, and an encysted dropsy which harl become general by breaking clown adhesions. The ovaries were licalthy.

Case 2 was that of a young ginl in whose aldomen a donbtful collection of thuid existerl. It was a very cliflicult case for diagnosis, bnt, on the whole, the anthor leaned to the view that it was a case of flaceid brond liganent cyst. Ablominal section showed that it was an encysted dropsy of the peritonem. The fluid was r'moverd, the sac cartefully spongrel out, and the incision closed withont clrainage. The pationt male a good recovery, the intestines graclually re-occupying the place where the fluid had been, and when she was last seen there was no appearance of re-arecumulation.

Mrr. Thornton urged the importane of the record of rare cases, and pointed out that the knowledge of this cliscase was still too limited for it to be possible to lay down rules as to diagnosis. He would aecept l'asslee's statement that encysterl clropsy of the peritoneum is always preceded and eansel by peritonitis. The canses of the peritonitis are, however, very various. With regind to treatment, he thought it right to open the alwhomen, and sponge ont the sare, in any" case in which the condition was diagnosed iu a pationt froe trom kirhucy disease;: drainage was not necessaly. Ihe urged the advantage of incision ats compareal with tappling, and spoke strongly as to the ralus of Listeriom in abrlominal suction, emplassizing his fath by his results in ovariotony at the Sammitan Hospital in 1881. During that year he harl had forty-one cases, lark not once chrained, and had only two deatlis, both occurring in young patients, the suljects of malignant tumour.-Lancet, Jan. 21, 1882.

\section{Malaria and Diabetes.}

At the meeting of the Acarlemie de IIedecine on November 29th, M. VknNEC1L communieated six obscrvations that he hat makle within the year, relative to surgrical aflections in persons aflected simultaneously with gylycosuria and millarial, and he presented an exteulded historical review of the anthors who had previonsly notel this association of discases. He cited in particular the memoir of 1). Burdel, presenterl to the Acarlemie des siciences in 1859, of which the followilg were the conclusions: 1. There exists a true diabetes in malaria. 2. 'l'his diabetes is only "plhemeral, that is to say, it appears with the fever, lasts dming its stay, and disappears with it. 3. The glycosuria of malarial fever reveals the disturbance which destroys the equilibrium between the cerebro-spinal and sympathetic neovous systems. 4. This explanation, given ly Claule Bernaril. is confirmed by the clinical faets. 5. The more violent the cases, and intense the fever, the greater the quantity of sugar in the urine. 6. When, on the reont 